\title{
Peningkatan Hasil Belajar Siswa Pada Materi Report Text Melalui PembelajaranBerdiferensiasi di Kelas IX.A SMP Negeri 1 Sape Tahun Pelajaran 2020/2021
}

\author{
Dedi Iskandar \\ SMP Negeri 1 Sape, Bima, Indonesia \\ *Coresponding Author: dediskandar2211@ gmail.com \\ Dikirim: 12-08-2021; Direvisi: 27-09-2021; Diterima: 28-09-2021
}

\begin{abstract}
Abstrak: Penelitian ini bertujuan untuk mengetahui sejauh mana peningkatan hasil belajar siswa kelas IX.A pada materi report text. Penelitian dilakukan pada Kelas IX.A di SMP Negeri 1 Sape semester 2 Tahun Pelajaran 2020-2021. Subjek penelitian sebayank 33 siswa. Metode yang digunakan dalam penelitian ini adalah metode penelitian tindakan kelas yang terdiri dari dua tindakan siklus yaitu I dan siklus II. Penelitian ini menggunakan metode penelitian kuantitatif berupa tes tulis dan metode penelitian kualitatif menggunakan lembar pengamatan dan lembar refleksi diri. Hasil penelitian menunjukkan bahwa pembelajaran berdiferensiasi dapat meningkatkan hasil belajar pada materi report text dengan pencapaian ketutasan belajar dari kondisi awal pra siklus diperoleh $36,36 \%$ menjadi $66,67 \%$ pada siklus I dan pada siklus II mencapai 90,91\%.
\end{abstract}

Kata Kunci: hasil belajar, report text, pembelajaran berdiferensiasi

Abstract: This study aims to determine the extent to which the improvement of student learning outcomes in class IX.A on report text material. The research was conducted in Class IX.A at SMP Negeri 1 Sape semester 2 for the 2020-2021 academic year. The research subjects were 33 students. The method used in this study is a classroom action research method which consists of two cycles of action, namely cycle I and cycle II. This study uses quantitative research methods in the form of written tests and qualitative research methods using observation sheets and self-reflection sheets. The results showed that differentiated learning could improve learning outcomes in report text material with the achievement of learning mastery from the initial pre-cycle conditions obtained $36.36 \%$ to $66.67 \%$ in the first cycle and in the second cycle it reached $90.91 \%$.

Keywords: learning outcomes, report text, differentiated learning

\section{PENDAHULUAN}

Pendidikan pada dasarnya merupakan sarana strategis untuk meningkatkan potensi bangsa agar mampu berkiprah dalam tataran yang lebih global sebagai sebuah investasi untuk mengembangkan kemampuan individu dan tataran kehidupan masyarakat. Pengembangkan sumber daya manusia menjadi tugas dan tanggung jawab pendidikan dalam menuntun potensi-potensi individu dengan memfasilitasi kebutuhanya sehingga mampu memahami apa yang dipelajari dan menjadi anggota masyarakat untuk mencapai keselamatan dan kebahagiaan yang setinggi-tingginya.

Selanjutnya, hasil identifkasi diperoleh bahwa pelaksanaan pendidikan masih belum banyak perubahan, dimana masih menerapkan sistem pembelajaran yang menganggap semua anak adalah sama tanpa melihat keberagaman kemampuannya. Guru seolah-olah mengajar satu orang murid dalam satu kelas, sedangkan dalam satu kelas tersebut diperkirakan lebih kurang 20-30 siswa yang mempunyai keunikan, 
kemampuan dan keberagaman pengalaman belajar, sehingga tidak jarang murid merasa jenuh dan akhirnya tidak/sedikit memiliki motivasi belajar yang baik. Seyogyanya, pendidikan haruslah sadar bahwa setiap anak adalahunik dan memiliki karakteristik yang berbeda dengan anak yang lainnya. Hal ini berarti bahwa penyeragaman hal-hal yang tidak perlu diseragamkan menjadi sebuah budaya pada proses pembelajaran tanpa membedakan minat, bakat, kesiapan belajar, profil belajar serta keadaan hidup anak dan masyarakat yang satu dengan lainya harus menjadi perhatian dan diakomodasi.

Oleh karena itu, pendidikan seharusnya bisa mengakomodasi dari semua perbedaan ini, terbuka untuk semua dan memberikan kebutuhan-kebutuhan yang dibutuhkan oleh setiapindividu. Keberagaman dari setiap individu murid harus selalu diperhatikan, karena setiap peserta didik tumbuh di lingkungan dan budaya yang berbeda sesuai dengan kondisi geografis tempat tinggal mereka. Berkenaan dengan hal tersebut, sepatutnya guru dapat mendesaian pembelajaran yang memperhatikan keberagaman siswa supaya pembelajaran yang dihasilkan mampu memenuhi kebutuhan belajar murid.

Selajutnya, berdasarkan data awal pada kelas IX.A SMP Negeri 1 Sape menunjukkanbahwa hasil belajar siswa masih kurang pada materi report text dimana tidak ada siswa yang mendapatkan nilai amat baik dari rentang nilai sesuai dengan $K K M \geq 92$. Kemudian, 4 siswayang mendapatkan nilai baik dari rentang nilai sesuai dengan KKM 81-91 dan 8 siswa memiliki rentang nilai sesuai dengan 75-83 dan 21 siswa memperoleh nilai $<75$ sehingga persentase ketuntasan secara klasikal pada kelas IX.A tergolong masih sangat kurang yaitu 33,33\%.

Berdasarkan data tersebut siswa kelas IX.A disimpulkan masih kesulitan pada materi report text dalam mata pelajaran Bahasa Inggris. Hal ini disebabkan karena adanya beberapa faktor antara lain: aspek kebahasaan (misalnya: pemakaian kosa kata yang tepat, tata bahasayang baik dan benar, penggunaan ejaan dan tanda baca yang benar), kesamaan materi antara siswa, model pembelajaran yang monoton, kurang menariknya materi belajar siswa, belum adanya pemetaan minat profil belajar siswa. Oleh karena itu, peneliti berusaha mencari solusi terbaik dengan mengahadirkan pembelajaran yang menyenangkan dalam menyajikan materi report text yang bertujuan untuk meningkatkan hasil belajar siswa melalui pembelajaran berdiferensiasi.

\section{KAJIAN TEORI (opsional)}

\section{Belajar}

Hamalik (2001:27) mengemukakan pengertian belajar adalah suatu proses perubahan tingkah laku individu melalui interaksi dengan lingkungan. Hal ini sesuai dengan pendapat Suparwoto (2004:41) bahwa belajar pada intinya adalah proses internalisasi dalam diri individu yang belajar dapat dikenali produk belajarnya yaitu berupaperubahan, baik penguasaan materi, tingkah laku, maupun keterampilan.

Lebih lanjut, Sudjana (2005: 22) mendefinisikan belajar adalah suatu proses usaha yang dilakukan individu untuk memperoleh suatu perubahan tingkah laku yang baru keseluruhan, sebagai hasil pengalaman individu itu sendiri dalam interaksinya dengan lingkungan.

Hamalik (1993: 280) mengungkapkan empat prinsip belajar yaitu :

@ 2021 JPPI (https://jurnal.bimaberilmu.com/index.php/jppi) 
a. Belajar senantiasa harus bertujuan, terarah, dan jelas bagi siswa, karena tujuan akan menuntut dalam belajar,

b. Jenis belajar yang paling utama adalah untuk berpikir kritis,

c. Belajar memerlukan pemahaman atas hal-hal yang dipelajari sehingga memperoleh pengertian-pengertian,

d. Belajar harus disertai keinginan dan kemauan yang kuat untuk mencapai tujuan danhasil.

Dari prinsip-prinsip tersebut memberikan penjelasan dalam memaknai belajar dan dapat mengetahui apa saja yang perlu diperhatikan dalam mendukung proses pembelajaran, sehingga pengertian dan pemahaman mengenai makna belajar menjadi lebih jelas dan terarah.

Dari pendapat di atas dapat disimpulkan bahwa di dalam belajar ada suatu perubahan tingkah laku dalam diri seseorang berupa pengetahuan, pemahaman, maupun sikap yang diperoleh melalui proses belajar. Perubahan tingkah laku yang diperoleh merupakan hasil interaksi dengan lingkungan. Interaksi tersebut salah satunya adalah prosespembelajaran yang diperoleh di sekolah. Oleh karena itu dapat dikatakan bahwa dengan belajar seseorang dapat memperoleh sesuatu yang baru baik itu pengetahuan, keterampilanmaupun sikap.

\section{Hasil Belajar}

Menurut Sudjana (2005:20) hakikat hasil belajar adalah perubahan tingkah laku individu yang mencakup aspek kognitif, afektif, dan psikomotorik. Kemudian, Sudjana (2005: 38) mengatakan bahwa hasil belajar yang dicapai siswa dipengaruhi oleh dua faktor utama yakni faktor dari dalam diri siswa itu dan faktor yang datang dari luar diri siswa atau faktor lingkungan. Faktor yang datang dari diri siswa terutama kemampuan yang dimilikinya. Faktor kemampuan siswa besar sekali pengaruhnya terhadap hasil belajar yang dicapai. Disamping faktor kemampuan yang dimiliki siswa, juga ada faktor lain, seperti motivasi belajar, minat dan perhatian, sikap dan kebiasaan belajar, ketekunan, sosial ekonomi, faktor fisik dan psikis.

Dalam sistem pendidikan nasional rumusan tujuan pendiikan, baik tujuan kurikuler maupun tujuan instruksional, menggunakan hasil belajar dari Anderesen (Darmawan dan Sujoko, 2013:35) yang secara garis besar membaginya dalam tiga ranah yaitu ranah kognitif, ranah afektif dan ranah psikomotor.

a. Ranah kognitif

Ranah kognitif adalah perubahan perilaku yang terjadi dalam kawasan kognisi. Proses belajar yang melibatkan kawasan kognisimeliputi kegiatan sejak dari penerimaan stimulus, penyimpanan dan pengolahan dalam otak menjadi informasi hingga pemanggilan kembali informasi ketika diperlukan untuk menyelesaikan masalah. Secara hirarki tingkat hasil belajar kognitif mulai dari yang paling rendah dan sederhana yaitu hafalan sampai yang paling tinggi dan kompleks yaitu evaluasi. Enam tingkatan itu adalah pengetahuan (C1), pemahaman (C2), penerapan (C3), analisis (C4), evaluasi (C5) dan menyciptakan (C6) Menciptakan.

1) Pengetahuan (knowledge) yaitu kemampuan seseorang untuk mengingat kembali tentang nama, istilah, ide, gejala, rumus- rumus dan lain sebagainya, tanpa mengharapkan kemampuan untuk menggunakannya.

2) Pemahaman (comprehension) yakni kemampuan seseorang untuk memahami sesuatu setelah sesuatu itu diketahui dan diingat melalui penjelasan dari katakatanya sendiri. 
3) Penerapan (application) yaitu kesanggupan seseorang untuk menggunakan ideide umum, tata cara atau metode- metode, prinsip-prinsip, rumus- rumus, teoriteori, dan lain sebagainya dalam situasi yang baru dan kongkret.

4) Analisis (analysis) yakni kemampuan seseorang untuk menguraikan suatu bahan atau keadaan menurut bagian- bagian yang lebih kecil dan mampu memahami hubungan diantara bagian- bagian tersebut.

5) Evaluasi (evaluation) yang merupakan jenjang berfikir paling tinggi dalam ranah kognitif menurut Taksonomi Bloom. Penelitian disini adalah kemampuan seseorang untuk membuat pertimbangan terhadap suatu situasi, nilai atau ide, atas beberapa pilihan kemudian menentukan pilihan nilai atau ide yang tepat sesuai kriteria yang ada.

6) Menciptakan yakni memadukan unsur-unsur /bagian- bagian ke dalam sesuatu yang baru dan utuh atau untuk membuat sesuatu produk yang orisinil.

b. Ranah Afektif

Kratwohl (Purwanto, 2008:51) membagi belajar afektif menjadi lima tingkat, yaitu penerimaan (merespon rangsangan), partisipasi, penilaian (menentukan pilihan sebuah nilai dari rangsangan), organisasi (menghubungkan nilai-nilai yang dipelajari), dan internalisasi (menjadikan nilai-nilai sebagai pedoman hidup). Hasil belajar disusun secara hirarkis mulai dari tingkat yang paling rendah hingga yang paling tinggi. Jadi ranah afektif adalah yang berhubungan dengan nilai-nilai yang kemudian dihubungkan dengan sikap dan perilaku.

\section{c. Ranah Psikomotorik}

Beberapa ahli mengklasifikasikan dan menyusun hirarki dari hasi belajar psikomotorik. Hasil belajar disusun berdasarkan urutan mulai dari yang paling rendah dan sederhana sampai yang paling tinggi hanya dapat dicapai apabila siswa telah menguasai hasil belajar yang lebih rendah. Simpson (Purwanto, 2008 : 51) mengklasifikasikan hasil belajar psikomotorik menjadi enam yaitu,persepsi (membedakan gejala), kesiapan (menempatkan diri untuk memulai suatu gerakan), gerakan terbimbing (meniru model yang dicontohkan), gerakan terbiasa (melakukan gerakan tanpa model hingga mencpai kebiasaan), gerakan kompleks (melakukan serang serangkaian gerakan secara berurutan), dan kreativitas (menciptakan gerakan dan kombinasi gerakan baru yang orisinil atau asli).

Ketiga ranah di atas menjadi obyek penilaian hasil belajar. Kemudian dapat disimpulkan bahwa hasil belajar adalah peubahan perilaku yang terjadi setelah mengikuti proses belajar mengajar sesuai dengan tujuan yang telah ditetapkan. Manusia memiliki potensi perilaku kejiwaan yang dapat dididik dan diubah perilakunya yang meliputi aspek kognitif, afektif dan psikomotorik.

Berdasarkan uraian diatas hasil belajar merupakan perubahan tingkah laku individu yang mencakup tiga aspek yaitu kognitif, afektif, dan psikomotorik. Hasil belajar juga merupakan suatu perubahan tingkah laku dari belum bisa menjadi bisa dan dari yang belum tahu menjadi tahu. Hasil belajar pada penelitian ini menitikberatkan pada hasil belajar yang berupa kognitif. Hasil belajar kognitif dapat diukur melalui tes dan dapat dilihat dari nilai yang diperoleh. Dalam penelitian ini hasil belajar dikhususkan pada tingkat pengetahuan (C1) sampai tingkat analisis (C4).

\section{Faktor Yang Mempengaruhi Hasil Belajar}


Berhasil atau tidaknya seseorang dalam belajar disebabkan beberapa factor yang mempengaruhi pencapaian hasil belajar. Dalyono (2009: 55) mengemukakan faktor-faktor yang mempengaruhi hasil belajar yaitu faktor internal dan faktor eksternal. Factor internal meliputi kesehatan, intelegensi dan bakat, minat dan motivasi, dan cara belajar. Sedangkan factor eksternal meliputi keluarga, sekolah, masyarakat dan lingkungan sekitar.

a. Faktor internal, yaitu faktor yang berasal dari dalam diri, meliputi:

1. Kesehatan

Kesehatan jasmani dan rohani sangat besar pengaruhnya terhadap kemampuan belajar. Bila seseorang tidak sehat dapat mengakibatkan tidak bergairah untuk belajar. Demikian pula jika kesehatan rohani kurang baik dapat menganggu atau mengurangi semangat belajar. Dengan semangat belajar yang rendah tentu akan menyebabkan hasil belajar yang rendah pula.

2. Intelegensi dan bakat

Kedua aspek kejiwaan ini besar sekali pengaruhnya terhadap kemampuan belajar. Seseorang yang memiliki intelegensi baik (IQ- nya tinggi) umumnya mudah belajar dan hasilnya cenderung baik. Sebaliknya orang yang intelegensinya rendah, cenderung mengalami kesulitan dalam belajar, lambat berpikir, sehingga hasil belajarnya pun rendah. Orang yang memiliki bakat akan lebih mudah dan cepat pandai bila dibandingkan dengan orang yang tidak memiliki bakat. Bila seseorang mempunyai intelegensi tinggi dan bakat dalam bidang yang dipelajari, maka proses belajarnya akan lancar dan sukses.

3. Minat dan motivasi

Minat dan motivasi adalah dua aspek psikis yang besar pengaruhnya terhadap pencapaian hasil belajar. Minat belajar ynag besar cenderung memperoleh hasil belajar yang tinggi, sebaliknya minat belajar kurang akan memperoleh hasil belajar yang rendah. Seseorang yang belajar dengan motivasi yang kuat, akan melaksanakan semua kegiatan belajarnya dengan sungguh - sungguh, penuh gairah atau semangat. Kuat lemahnya motivasi belajar seseorang turut mempengaruhi hasil belajar. Minat dan motivasi belajar ini dapat juga dipengaruhi oleh cara guru dalam menyampaikan materi pembelajaran. Guru yang menyampaikan materi dengan metode dan cara yang inovatif akan mempengaruhi juga minat dan motivasi siswanya.

4. Cara belajar

Cara belajar seseorang juga mempengaruhi pencapaian hasil belajar. Belajar tanpa memperhatikan teknik dan faktor fisiologis, psikologis, dan ilmu kesehatan akan memperoleh hasil yang kurang memuaskan. Cara belajar antar anak berbeda - beda. Ada anak yang dapat dengan cepat menyerap materi pelajaran dengan cara visual atau melihat langsung, audio atau dengan cara mendengarkan dari orang lain dan ada pula anak yang memiliki cara belajar kinestetik yaitu dengan gerak motoriknya misalnya dengan cara berjalan - jalan dan mengalami langsung aktivitas belajarnya.

b. Faktor eksternal, yaitu faktor yang berasal dari luar diri, meliputi:

1. Keluarga

Keluarga sangatlah besar pengaruhnya terhadap keberhasilan siswa dalam belajar. Tinggi rendahnya pendidikan orang tua, besar kecilnya 
penghasilan, cukup atau kurang perhatian dan bimbingan orang tua, kerukunan antar anggota keluarga, hubungan antara anak dengan anggota keluarga yang lain, situasi dan kondisi rumah juga mempengaruhi hasil belajar.

2. Sekolah

Keadaan sekolah tempat belajar mempengaruhi keberhasilan belajar. Kualitas guru, metode mengajar, kesesuaian kurikulum dengan kemampuan siswa, keadaan fasilitas di sekolah,keadaan ruangan, jumlah siswa perkelas, pelaksanaan tata tertib sekolah, dan sebagainya, semua mempengaruhi hasil belajar siswa. Metode pengajaran guru yang inovatif dapat pula mempengaruhi hasil belajar siswa. Metode mengajar dengan model koopertif misalnya, dengan siswa belajar secara kelompok dapat merangsang siswa untuk mengadakan interaksi dengan temannya yang lain. Teknik belajar dengan teman sebaya pun dapat mengaktifkan keterampilan proses yang dimiliki oleh anak.

3. Masyarakat

Keadaan masyarakat juga menentukan hasil belajar siswa. Bila di sekitar tempat tinggal siswa keadaan masyarakatnya terdiri dari orang - orang yang berpendidikan, akan mendorong siswa lebih giat lagi dalam belajar. Tetapi jika di sekitar tempat tinggal siswa banyak anak - anak yang nakal, pengangguran, tidak bersekolah maka akan mengurangi semangat belajar sehingga motivasi dan hasil belajar berkurang.

4. Lingkungan sekitar

Keadaan lingkungan tempat tinggal, juga sangat mempengaruhi hasil belajar. Bila rumah berada pada daerah padat penduduk dan keadaan lalu lintas yang membisingkan, banyak suara orang yang hiruk pikuk, suara mesin dari pabrik, polusi udara, iklim yang terlalu panas, akan mempengaruhi gairah siswa dalam belajar. Tempat yang sepi dan beriklim sejuk akan menunjang proses belajar siswa.

Berdasarkan uraian di atas metode pengajaran yang terapkan oleh guru untuk menyampaikan materi pembelajaran termasuk ke dalam faktor eksternal yang kemudian secara berkelanjutan akan mempengaruhi faktor internal anak. Faktor eksternal yang dimaksudkan dalam hal ini adalah faktor yang berasal dari sekolah yaitu metode pembelajaran. Metode pembelajaran yang inovatif akan berpengaruh terhadap minat dan motivasi (faktor internal) siswa dalam mengikuti proses pembelajaran. Salah satu model pembelajaran yang inovatif dan menyenangkan untuk siswa adalah model pembelajaran berdiferensiasi. Dengan model pembelajaran melalui tipe ini diharapkan hasil belajar siswa lebih meningkat.

\section{Manfaat Hasil Belajar.}

Sudjana dan Ibrahim (2009:3) mengatakan bahwa hasil belajar pada hakekatnya adalah perubahan tingkah laku seseorang yang mencakup kemampuan kognitif, afektif, dan psikomotor setelah mengikuti suatu proses belajar mengajar tertentu. Pendidikan dan pengajaran dikatakan berhasil apabila perubahan-perubahan yang tampak pada siswa merupakan akibat dari proses belajar mengajar yang dialaminya yaitu proses yang ditempuhnya melalui program dan kegiatan yang dirancang dan dilaksanakan oleh guru dalam proses pengajarannya. Berdasarkan 
hasil belajar siswa, dapat diketahui kemampuan dan perkembangan sekaligus tingkat keberhasilan pendidikan.

Hasil belajar harus menunjukkan perubahan keadaan menjadi lebih baik, sehingga bermanfaat untuk: (a) menambah pengetahuan, (b) lebih memahami sesuatu yang belum dipahami sebelumnya, (c) lebih mengembangkan keterampilannya, (d) memiliki pandangan yang baru atas sesuatu hal, (e) lebih menghargai sesuatu daripada sebelumnya. Dapat disimpulkan bahwa istilah hasil belajar merupakan perubahan dari siswa sehingga terdapat perubahan dari segi pegetahuan, sikap, dan keterampilan.

\section{Teks report (report text)}

a. Definisi

Tujuan Komunikatif dari Report text adalah menyampaikan informasi tentang suatu subjek. Teks report biasanya berisikan fakta-fakta, deskripsi dan informasi tentang subjek tersebut, terutama bagian-bagian, prilaku dan kualitasnya.

b. Generic Structure Report text

Di setiap Report text terdapat dua bagian yang menjadi ciri dari Report text itu sendiri. Kedua bagian tersebut adalah:

1. General Classification

General classification atau klasifikasi umum merupakan pernyataan umum yang menerangkan subjek laporan, keterangan, dan klasifikasinya. Bagian ini menyatakan klasifikasi aspek umum untuk hal-hal seperti hewan, tempat umum, tanaman, dan lain-lain. Contohnya seperti ini. Pigeon refers to all birds of the family Columbidae and order Columbiformes. They consist of 310 species. Some people may also know them as "Doves".

2. Descriptions.

Descriptions (keterangan) merupakan bagian dari teks laporan informasi yang memberikan gambaran fenomena atau situasi yang terjadi, baik bagianbagiannya, sifat, kebiasaan maupun tingkah lakunya. Bagian ini menjabarkan klasifikasi yang disajikan secara ilmiah, terlihat dari penggunaan nama ilmiah objek yang dilaporkan, atau dengan penjelasan fitur-fitur dan fungsi khusus yang dimiliki oleh objek yang bersangkutan.

c. Ciri Kebahasan Report text

Adapun ciri kebahasaan Report text antara lain:

1) Menggunakan nomina umum (general nouns), seperti Reptiles in Comodo

2) Menggunakan verba kopula atau penghubung (relating verbs) untuk menjelaskan ciri, misalnya Reptiles are scaly animals (ciri ini berlaku untuk semua reptilia).

3) Menggunakan verba tindakan (action verbs) dalam menjelaskan perilaku, misalnya Lizards cannot fly.

4) Menggunakan waktu kini (present tense) untuk menyatakan suatu yang umum, misalnya Komodo dragons usually weight more than $160 \mathrm{~kg}$.

5) Menggunakan istilah teknis atau ilmiah, misalnya Water contains oxygen and hydrogen.

\section{Pembelajaran berdiferensiasi}

Tomlinson mengatakan bahwa pembelajaran berdiferensiasi dapat dilakukan dengan tiga hal; (1) kesiapan belajar; (2) minat (3) profil belajar. Selanjutnya Tomlinson (2001:1) menjelaskan bahwa "difeerentiated instruction includes 
teachers' proactive plan to through concern with providing ways for students to access knowledge by giving various approaches on the content, process, and product". Pernyataan tersebut dapat diartikan bahwa dalam pembelajaran diferensiasi termasuk sebuah rencana proaktif guru dalam menyiapkan cara untuk mengakses kemampan siswa dengan memberikan berbagai pendekatan pada konten, proses dan produk.

Dari pemikiran diatas diasumsikan bahwa beberapa strategi yang perlu diperhatikan dalam mencapai kesuksesan anak dalam pembelajaran berdiferensiasi yaitu difernsiasi konten, proses dan produk. Pada pembelajaran berdiferensiasi konten menitikberatkan pada apa yang diajarakan pada murid. Sebuah konten dapat dibedakan dari tanggapan, tingkat kesiapan, kombinasi dari kesiapan, minat dan profil belajar muird. Hal tersebut berfungsi untuk mengukur readiness atau kesiapan murid. Oleh karena itu, dalam memetakan kebutuahn berdasarkan kesiapan murid maka perlu ditentukan jenis informasi yang harus disiapkan berupa bahan belajar bersifat foundational dan transformational. Bahan belaajar yang bersifat foundational atau mendasar misalnya dasar-dasar, fakta umum, prinsip-prinsip yang pada hakikatnya berada pada level mendasar. Disisi lain, bahan ajar transformational merupakan bahan ajar yang diperlukan dalam menumbuhkan ide-ide berupa, research question, tantangan, pertanyaan-pertanyaan pemandu yang dapat membantu mereka mengembangkan pemahaman dan memperluas ide secara lebih dalam sehingga berproses melangkah pada pembealajaran yang bersifat bstrask dan konkrit.

Lebih lanjut, diferensiasi proses merupakan memaknai apa informasi dan materi dalam proses pembelajaran yang disiapkan dan dipertimbangkan dalam skenario pelajaran dengan cara berjenjang dimana semua murid bekerja; menyediakan pertanyaan pemandu yang perlu diselesaikan di sudut-sudut minat terkait topik yang menarik minat mereka (olahraga dsb); membuat agenda individu untuk murid yaitu membuat daftar tugas untuk seluruh kelas, jika sudah selesai agenda personal; memvariasikan waktu untuk membantu murid menyelesaikan tugas; pengelompokan fleksibel sesuai dengan kesiapan, kemampuan dan minat serta pengekolompokan gaya belajar visual, auditory, kinestetik.

Kemudian, pada pembelajaran berdiferensiasi produk terfokus pada tagihan dan hasil pekerjaan atau unjuk kerja yang berbentuk berupa video visual presentasi siswa, video presentasi audio siswa, rekaman suara, dan tulisan siswa sesuai dengan pemahaman murid. Hal tersebut berarti bahwa setiap siswa belajar dengan materi yang sama namun konten yang berbeda, proses yang berbeda dan produk yang dihasilkan berbeda namun memiliki titik akhir individu.

Oleh karena itu sebuah pembelajran berdiferensiasi hendaknya mampu memetakan kekuatan semua siswa pada masing-masing bidangnya dan yang dibutuhkan sesuai dengan minat dan cara belajar serta waktu belajar yang berbeda. Lebih lanjut, pembelajaran berdiferensiasi seyogyanya perlu ditumbuhkembangkan dalam komunitas belajar (learning community). Senada dengan pemikiran tersebut Heacox (2003:6) mengatakan bahwa teaching using differentiated instruction needs to pay attention on students' readiness, interest, learning profile, and learning environment...It needs the ability of teacher to provide choices for content, process, and product. Pemikiran tersebut dapat diartikan bahwa mengajar dengan menggunakan pembelajaran diferensiasi membutukan perhatian siswa dalam kesiapan, minat, profil belajar dan lingkungan pembelajaran. Hal tersebut dibutuhkan 
kemampuan guru dalam menyediakan materi pilihan pada konten, proses dan produk,

Pemikiran tersebut menguraikan bahwa pembelajaran diferensiasi merupakan suatu usaha mencampurkan semua perbedaan untuk mendapatkan suatu informasi, membuat ide dan mengekspresikan apa yang akan dipelajari dengan mengelola suatu kelas yang beragam dan memberikan kesempatan dalam mempelajari konten materi, memproses konten materi kedalam suatu ide dan meningkatkan hasil setiap murid, sehingga murid- murid akan bisa lebih belajar dengan efektif.

Lebih lanjut, Tomlinson (2001:1) mengatakan bahwa It gives students multiple options for learning content that demonstrate their understanding, skill, and knowledge and express it in different products that suit their level of mastery. Pemikiran tersebut diartikan secara bebas bahwa pembelajaran diferensiasi memberikan siswa berbagai pilihan untuk belajar konten materi yang mendemonstrasikan pemahaman mereka, kemampuan, pengetahuan dan mengekspersikannya pada produk/hasil berbeda sesuai dengan level pemahamannya.

Berdasakan sudut pandang tersebut dapat dianalogikan bahwa apabila guru memberikan tugas membaca kepada murid-muridnya sepatutnya mengetahui tingkat level kemampuan membaca muridnya sehingga mampu memberikan tugas membaca sesuai dengan tingkat level membaca murid tersebut dan juga mampu mengaitkannya dengan ketertarikan (minat) murid. Oleh karena itu, pembelajaran diferensiasi yang hendak dilaksanakan tidak menambah beban murid-murid dalam belajar tetapi justru menciptakan suasana belajar yang menyenangkan dan merangsang anak untuk terus belajar yang pada akhirnya membantu anak dalam mencapai kesuksesan dalam belajar. Hal ini selaras dengan yang dikatakan oleh Jamoliddinova (2019:321) pada artikelnya bahwa the differentiated instruction improves students' learning achievement.

Oleh karena itu, dalam penerapan pembelajaran berdiferensiasi diperlukan iklim kelas yang mendukung dimana setiap orang di dalam kelas akan menyambut dan merasa disambut dengan baik, setiap orang saling menghargai, murid semaksimal mungkin merasa aman dalam belajar, ada harapan pada pertumbuhan pada penguasaan murid, guru mengajar untuk mencapai kesuksesan murid, ada keadilan yang dirasakan murid dalam bentuk yang nyata, guru dan siswa berkolaborasi untuk kesuksesan bersama.

Berdasarkan pemaparan di atas bahwa pembelajaran berdiferensiasi sepatutnya menumbuhkembangkan rasa hormat terdahap anak dengan keberagamanya masingmasing, dengan menggunakan beragam pendekatan yang memuat konten, proses dan produk dimana pelaksanaan kegiatanya berpusat pada murid.

\section{METODE PENELITIAN}

Penelitian ini merupakan penelitian tindakan kelas yang dirancang dalam dua siklus. Adapun tahapan perencanaan dan pelaksanaan kedua siklus tersebut pada prinsipnya adalah sama. Desain penelitian yang digunakan adalah penelitian tindakan kelas. Mulyasa (2009:35) menyatakan penelitian tindakan adalah kegiatan penelitian untuk mendapatkan kebenaran dan manfaaat praktis dengan melakukan tindakan secara kolaboratif dan partisipasif, yang melibatkan beberapa pihak yaitu guru, kepala sekolah maupun pihak yang luar dalam waktu yang sama. 


\section{Lokasi dan Waktu Penelitian}

Kegiatan penelitian dilaksanakan di SMP Negeri 1 Sape, Kecamatan Sape Kabupaten Bima. Penelitian dilaksanakan selama 2 bulan, yaitu pada semester genap mulai bulan Januari sampai dengan bulan Februari 2021. Pemberian tindakan dilakukan pada jadwal jam tatap muka peneliti yang merupakan hari/jam pelajaran dimana peneliti mengajar Bahasa Inggris di kelas IX.A yang menjadi subjek penelitian.

\section{Subyek Penelitian}

Subyek dalam penelitian ini adalah siswa kelas IX.A SMPN 1 Sape tahun pelajaran 2020/2021 berjumlah 33 orang.

\section{Instrumen Penelitian}

Instrumen dalam penelitian ini menggunakan tes tulis, lembar observasi, dan lembar refleksi diri.

\section{Sumber Data dan Teknik Pengumpulan Data}

Sumber data penelitian ini, yaitu sumber data primer dan sumber data sekunder. Sumber data primer pada penelitian ini diambil dari: 1) hasil pre-test siswa sebelum tindakan berlangsung; 2) hasil lembar refleksi diri siswa; 3) hasil belajar siswa pada setiap siklus tindakan; 4) hasil observasi tentang sikap belajar siswa pada saat proses pembelajaran; 5) hasil observasi atau pengamatan mengenai kegiatan belajar dan sikap belajar siswa yang dikumpulkan selama tindakan berlangsung dari rekan sejawat. Sedangkan sumber data sekunder pada penelitian ini diperoleh dari: 1) data mengenai jumlah siswa-siswi kelas IX.A yang diperoleh dari daftar hadir kelas; 2) data studi pustaka yang menunjang penyusunan penelitian ini. Sementara, teknik yang digunakan ada 2 (dua) macam yaitu tes dan non-tes. Teknik tes yang digunakan untuk mengukur kemajuan hasil belajar siswa adalah tes tulis.

Sedangkan teknik non-tes berupa observasi perilaku belajar siswa selama proses pembelajaran berlangsung dan lembar refleksi diri siswa setelah setiap siklus selesai dilaksanakan.

Alat pengumpulan data yang digunakan dalam penelitian ini meliputi : lembar soal pre- test sebelum siklus I tentang materi report text tanpa menggunakan pembelajaran diferensiasi; lembar rubrik penilaian (rubric assessment sheet) yang dipakai untuk mengukur kemampuan siswa pada materi report text digunakan peneliti untuk menilai produk; lembar refleksi diri siswa digunakan untuk menggali keberhasilan, kendala serta pembelajaran yang dihadapi siswa dalam proses pembelajaran siklus I; lembar pengamatan yang digunakan oleh rekan sejawat untuk mencatat aktivitas dan tingkat motivasi siswa selama proses pembelajaran berlangsung; studi pustaka tentang peningkatan hasil belajar pada materi report text menggunakan pembelajaran berdiferensiasi untuk mendukung penelitian ini, dokumentasi yang berupa foto-foto tentang kegiatan siswa pada setiap siklus pembelajaran.

\section{Analisis Data}

Analisis data hasil penelitian peneliti menggunakan metode: (1) deskriptif, yaitu digunakan untuk upaya memecahkan masalah atau menjawab permasalahan yang dihadapi. (2) kualitatif, yaitu penggambaran dengan kata-kata atau kalimat yang dipisahkan dengan katagori analisis data deskriptif kualitatif yaitu analisis data yang 
tidak dapat diukur melalui perhitungan dengan angka-angka melainkan dengan menggunakan kata-kata.

Validasi penelitian tindakan kelas ini menggunakan triangulasi sumber dan triangulasi metode. Triangulasi sumber data berasal dari guru kelas, siswa dan rekan sejawat sebagai kolaborator. Sedangkan triangulasi metode yaitu data dari pengumpulan dokumen, hasil obeservasi dan hasil tes tulis.

Akhir dari pada penelitian tindakan kelas ini adalah tercapainya peningkatan hasil belajar siswa pada materi report text dan perubahan dalam sikap belajar siswa yang disesuaikan dengan nilai kriteria ketuntasan minimum pada mata pelajaran Bahasa Inggris

Tabel 1. Kriteria Ketuntasan Minimum (KKM)

\begin{tabular}{|l|l|l|}
\hline No & Nilai KKM & Predikat \\
\hline 1 & $\geq 92$ & Amat Baik \\
\hline 2 & $84-91$ & Baik \\
\hline 3 & $75-83$ & Cukup \\
\hline 4 & $<75$ & Kurang \\
\hline
\end{tabular}

\section{Prosedur Penelitian}

Penelitian ini dirancang untuk dilaksanakan dalam dua siklus yaitu siklus I dan siklus II melalui metode pembelajaran diferensiasi dimulai dari diferensiasi konten, diferensiasi proses, dan diferensiasi produk. Pemilihan metode tersebut disesuaikan dengan tujuan yang ingin dicapai pada Kompetensi Dasar 3.4 dan 4.4.1 - 4.4.2 (kurikulum penyederhanaan) untuk siswa kelas IX.A semester genap. Adapun tahapan perencanaan dan pelaksanaan kedua siklus tersebut pada prinsipnya adalah sama, sebagaimana pendapat Kemmis dan Mc Taggart (1988) dalam Trianto (2011: 30) bahwa siklus terdiri atas: a) perencanaan (Planning); b) tindakan (Acting); c) pengamatan (Observing); dan d) refleksi (Reflecting).

1. Perencanaan (Planning)

Tahap Perencanaan dimulai dari (1) merencanakan RPP dan skenario pembelajaran siklus I untuk dua kali pertemuan dengan alokasi waktu 2x30 menit per pertemuan; (2) Menyiapkan materi report text yang akan disajikan untuk siswa; (3) Mempersiapkan materi; (4) Menyiapkan pembelajaran berdiferensiasi yang akan digunakan siswa untuk membantu memahami materi report text; (5) Menyusun soalsoal evaluasi yang berkaitan dengan teks yang telah disiapkan; (6) Menyiapkan instrumen penilaian.

2. Pelaksanaan (Acting)

Kegiatan pembelajaran report text dilakukan terlebih dahulu agar siswa mendapatkan konsep report text dengan jelas. Guru memberikan pemahaman kepada siswa tentang social function, generic stucture dan language features pada report text. Selanjutnya guru memberi penjelasan tentang pembelajaran berdiferensiasi yang akan dipakai dalam upaya peningkatan hasil belajar siswa pada materi report text. Setelah memberikan penjelasan secara detail tentang report text dan pembelajaran berdiferensiasi, guru memberikan contoh teks berbentuk report dan bagaimana cara menulis report text. Setelah kegiatan tanya jawab antara guru dan siswa tentang menulis teks berbentuk report berlangsung, siswa mulai melakukan perintah guru menuliskan report text berbahasa Inggris dimulai dengan memilih konten materi 
yang diberikan sesuai dengan minat, memilih proses sesuai dengan kesiapanya dan membuat produk sesuai dengan profil belajarnya tentang materi pada report text.

3. Observasi (Observing)

Kegiatan observasi (pengamatan) yang harus dilakukan adalah mengamati perilaku siswa yang sedang mengikuti kegiatan pembelajaran berdiferensiasi pada materi report text pada mata pelajaran Bahasa Inggris di kelas IX.A SMP Negeri 1 Sape, memantau kegiatan diskusi atau kerja sama kelompok dalam menyiapkan pembelajaran berdiferensiasi, mengamati pemahaman tiap siswa dalam penguasaan memahami report text dan mengamati kegiatan siswa dalam menuangkan gagasannya dalam tulisan berbentuk report. Observasi dilakukan oleh teman guru yang sama mata pelajarannya, atau teman guru mata pelajaran serumpun menggunakan lembar penilaian observasi yang telah disiapkan oleh peneliti. Pengamat mencatat semua kejadian yang berlangsung dari awal pertemuan sampai akhir pertemuan serta memberikan catatan temuan-temuan selama proses pembelajaran berlangsung yang kemudian dijadikan sebagai acuan untuk lebih meningkatkan hasil belajar pada materi teks report pada mata pelajaran Bahasa Inggris pada siklus berikutnya.

4. Refleksi (Reflecting)

Kegiatan refleksi yang harus dilakukan oleh peneliti adalah mencatat hasil observasi, mengevaluasi hasil observasi, menganalisis hasil pembelajaran, mengolah data dari hasil lembar refleksi diri siswa, mencatat kelemahan-kelemahannya untuk dijadikan bahan penyusunan rancangan siklus berikutnya sampai tujuan PTK tercapai. Peneliti juga melakukan diskusi dengan guru observer untuk membicarakan kekurangan-kekurangan, kendala-kendala dalam pembelajaran yang perlu diperbaiki pada siklus berikutnya. Hasil yang diperoleh dari pengamatan dan hasil evaluasi pada siklus I, digunakan sebagai dasar apakah sudah memenuhi target atau perlu dilakukan penyempurnaan strategi agar di siklus II diperoleh hasil yang lebih baik.

Empat tahapan di atas tidak hanya dilakukan pada siklus I, tetapi juga dilaksanakan pada siklus II. Hasil refleksi dari Siklus I menjadi dasar bagi pelaksanaan siklus II terutama tahapan perencanaan dan tindakan. Pada siklus II dilakukan tindakan yang lebih baik, agar kekurangan-kekurangan yang terjadi di siklus I tidak terulang lagi di siklus II.

\section{HASIL DAN PEMBAHASAN}

\section{Deskripsi Kondisi Awal}

Pelaksanaan awal pembelajaran peneliti melakukan kegiatan pra siklus (pre test) pada materi report text tanpa menggunakan pembelajaran berdiferensiasi. Pra siklus dilakukan untuk mengetahui kondisi awal siswa sebelum dilakukan tindakan siklus I. Data yang diperoleh dari kondisi awal hasil belajar siswa kelas IX.A SMP Negeri 1 Sape sebelum dilakukan tindakan pada siklus I didapatkan hasil sebagai berikut.

Tabel 2. Hasil Tes Pra Siklus

\begin{tabular}{|l|l|l|l|l|}
\hline No & Nilai KKM & Jumlah Siswa & Persentase \% & Keterangan \\
\hline 1 & $\geq 92$ & 0 & 0 & Amat Baik \\
\hline 2 & $84-91$ & 4 & $12,12 \%$ & Baik \\
\hline 3 & $75-83$ & 8 & $24,24 \%$ & Cukup \\
\hline 4 & $<75$ & 21 & $64,63 \%$ & Kurang \\
\hline
\end{tabular}

@ 2021 JPPI (https://jurnal.bimaberilmu.com/index.php/jppi) 


\begin{tabular}{|l|l|l|l|}
\hline Jumlah & 33 & $100 \%$ & \\
\hline
\end{tabular}

Berdasarkan data di atas dapat dielaborasikan bahwa tidak ada siswa yang mendapatkan nilai amat baik, 4 orang siswa atau 12,12\% mendapatkan nilai baik, 8 siswa atau 24,24\% mendapatkan nilai cukup dan 21 siswa atau 64,63\% mendapatkan nilai kurang. Berdasarkan data tersebut diketahui bahwa ketuntasan belajar secara klasikal diperoleh 36,36\% dimana persentase ini masih kurang dari indikator nilai standar kriteria ketuntasan minimum yaitu 75 .

\section{Deskripsi Hasil Siklus I}

Berdasarkan hasil tes pra siklus yang diperoleh, peneliti mengambil tindakan pada siklus I yaitu menggunakan pembelajaran berdiferensiasi sebagai model pembelajaran yang membantu siswa untuk meningkatkan hasil belajar pada materi report text. Dari siklus I diperoleh hasil seperti terlihat pada tabel 3 di bawah ini:

Tabel 3. Hasil Tes Siklus I

\begin{tabular}{|l|l|l|l|l|}
\hline No & Nilai KKM & Jumlah Siswa & Persentase \% & Keterangan \\
\hline 1 & $\geq 92$ & 2 & $6,06 \%$ & Amat Baik \\
\hline 2 & $84-91$ & 6 & $18,18 \%$ & Baik \\
\hline 3 & $75-83$ & 14 & $42,42 \%$ & Cukup \\
\hline 4 & $<75$ & 11 & $33,33 \%$ & Kurang \\
\hline & Jumlah & 33 & 100 & \\
\hline
\end{tabular}

Berdasarkan data tersebut diperoleh bahwa hasil belajar siswa pada materi report text melalui pembelajaran berdiferensiasi mengalami peningkatan dimana terdapat 2 siswa atau 6,06\% mendapatkan nilai amat baik, 6 siswa atau 18,18\% mendapatkan nilai baik, 14 siswa atau 42,42\% mendapatkan nilai cukup sedangkan 11 siswa atau 33,33\% mendapatkan nilai kurang. Hal tersebut menunjukkan bahwa ketuntasan belajar klasikal mencapai $66,67 \%$. Oleh karena itu, peneliti berupaya untuk lebih meningkatkan hasil belajar siswa pada materi report text dengan mengambil sebuah keputusan untuk melakukan pembelajaran berdirefernsiasi pada siklus ke II sesuai dengan usulan observer (rekan sejawat) dan hasil yang diperoleh.

\section{Deskripsi Hasil Siklus II}

Pelaksanaan pembelajaran pada siklus II memiliki alur yang sama dengan skenario pembelajaran siklus I menggunakan kembali model pembelajaran diferensiasi dengan harapan dapat meningkatkan hasil belajar siswa pada materi report text. Pada siklus II perbaikan-perbaikan dilakukan dengan seoptimal mungkin mendapatkan hasil terbaik sehingga diperoleh hasil seperti terlihat pada tabel 4 di bawah ini:

Tabel 4. Hasil Tes dalam Siklus II

\begin{tabular}{|l|l|l|l|l|}
\hline No & Nilai KKM & Jumlah Siswa & Persentase \% & Keterangan \\
\hline 1 & $\geq 92$ & 9 & 27,27 & Amat Baik \\
\hline 2 & $84-91$ & 14 & 42,42 & Baik \\
\hline 3 & $75-83$ & 7 & 21,21 & Cukup \\
\hline 4 & $<75$ & 3 & 9,09 & Kurang \\
\hline & Jumlah & 33 & 100 & \\
\hline
\end{tabular}


Berdasarkan data tersebut dapat diketahui bahwa hasil belajar siswa pada materi report text melalui pembelajaran berdiferensiasi mengalami peningkatan. Dari 33 siswa yang menjadi sampel terdapat 9 siswa atau 27,27\% mendapatkan nilai amat baik, 14 siswa atau $42,42 \%$ dan terdapat 7 siswa atau $21,21 \%$ mendapatkan nilai cukup, serta masih terdapat 3 orang atau 9,09\% yang masih memiliki nilai yang kurang. Dari data tersebut menunjukkan bahwa pencapaian hasil belajar siswa mencapai 90,91\%\% dengan standar kriteria ketuntasan minimum 75 . Hal ini dapat disimpulkan bahwa pembelajaran berdiferensiasi dapat meningkatkan hasil belajar siswa secara signifikan.

Oleh karena itu, peniliti berupaya mengkomparisasi hasil belajar siswa yang dimulai dengan pra siklus, siklus I dan siklus II pada tabel 5 dan diagram di bawah ini.

Tabel 5. Komparisasi Persentase Hasil Belajar Antar Siklus

\begin{tabular}{|l|c|c|c|}
\hline \multirow{2}{*}{ NILAIKKM } & \multicolumn{3}{|c|}{ Persentase Hasil Belajar } \\
\cline { 2 - 4 } & PRA SIKLUS & SIKLUS I & SIKLUS 2 \\
\hline $\mathbf{2 9 2}$ & $0 \%$ & $6,06 \%$ & $27,27 \%$ \\
\hline $\mathbf{8 4 - 9 1}$ & $12,12 \%$ & $\begin{array}{c}18,18 \\
\%\end{array}$ & $42,42 \%$ \\
& & 42,42 & $21,21 \%$ \\
$\mathbf{7 5 - 8 3}$ & $24,24 \%$ & 33,33 & $9,09 \%$ \\
\hline$<75$ & $64,63 \%$ & $\%$ & \\
\hline
\end{tabular}

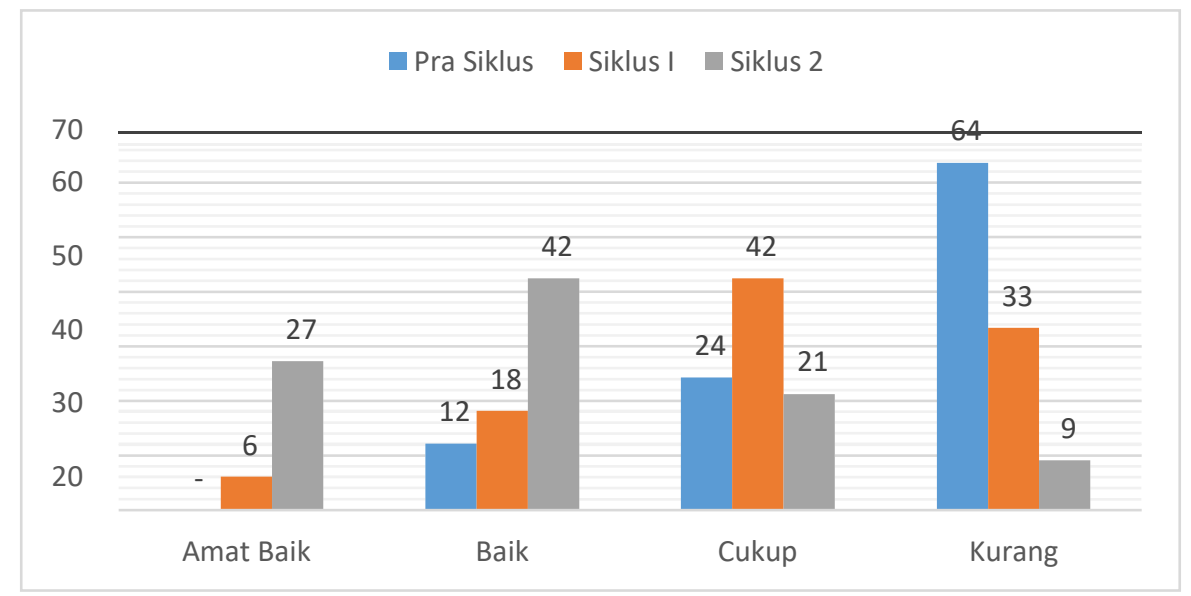

Gambar 1. Diagram Komparisasi Hasil Belajar Siswa

Berdasarkan data pada tabel 5 dan diagram 1 komparisasi di atas dapat dielaborasikan bahwa:

1. Hasil belajar siswa materi report text dengan nilai amat baik pada pra siklus sebanyak 0\%, sementara pada siklus I sebanyak 6\% dan siklus II sebanyak $27 \%$.

2. Hasil belajar siswa materi report text dengan nilai baik pada pra siklus sebanyak $12 \%$, sementara pada siklus I sebanyak $18 \%$ dan siklus II sebanyak $42 \%$.

3. Hasil belajar siswa materi report text dengan nilai cukup pada pra siklus sebanyak $24 \%$, sementara pada siklus I sebanyak $42 \%$ dan siklus II sebanyak $21 \%$. 
4. Hasil belajar siswa materi report text dengan nilai kurang pada pra siklus sebanyak 64\%, sementara pada siklus I sebanyak 33\% dan siklus II sebanyak $9 \%$.

Berdasarkan data diatas dapat disimpulkan bahwa hasil belajar siswa mengalami peningkatan dari kondisi awal pra siklus diperoleh $36,36 \%$ menjadi $66,67 \%$ pada siklus I dan menjadi $90,91 \%$ pada siklus II dengan standar kriteria ketuntasan minimum 75 .

\section{Hasil Non Tes}

Hasil non tes mencakup hasil yang diperoleh dari hasil refleksi pembelajaran dan observasi. Hasil tersebut menunjukkan bahwa siswa merasa senang, termotivasi dan kreatif sehingga lebih semangat belajar untuk memperoleh hasil belajar yang lebih baik.

Berdasarkan hasil refleksi pembelajaran menggunakan lembar refleksi https://s.id/refleksireportsmp1sp yang telah direduksi bahwa siswa merasa senang belajar teks report melalui pembelajaran diferensiasi. Kemudian, beberapa hal yang sudah dipelajari dalam pembelajaran diferensiasi pada materi teks report diperoleh data dari hasil reduksi data bahwa siswa mempelajari konsep mind mapping dalam memahami materi report text dan cara menyusunnya yang menggambarkan kebiasaan, habitat, ciri-ciri fisik dan emosioanl dari berbagai macam hewan persilangan.

Selanjutnya, berdasarkan data yang diperoleh dari lembar refleksi tentang hal yang telah dikuasai pada materi teks report diperoleh data dari hasil reduksi data bahwa siswa mampu menulis teks report, menyimpulkan teks, dan memahami struktur dan tata bahasa report text, namun masih ada siswa yang belum memahami materi report text.

Lebih lanjut, hal yang menarik ketika dilaksanakan pembelajaran diferensiasi pada materi report text diperoleh data dari hasil reduksi data bahwa siswa senang belajar secara kelompok dan pengelompokan sesuai dengan minat masing-masing. Kemudian, siswa senang dapat melakukan diskusi karena banyak pertimbangan pendapat yang berbeda-beda, mengajukan pertanyaan kepada kelompok lain dan memberikan jawabannya, disamping itu siswa mampu mengetahui keunikan hewan pilihannya berdasarkan ciri-ciri fisik, habitat, kebiasaan dan lainya menggunakan konsep mind mapping.

Hal yang terakhir diperoleh data dari hasil reduksi data tentang hal yang tidak menarik dalam pembelajaran bahwa siswa merasa pembelajaran pada materi report text dinilai menarik namun masih terdapat kendala dimana ketika kelompok lainya yang presentasi masih ada siswa yang bicara dengan temannya sehingga mengganggu konsentrasi belajar.

Berdasarkan pemaparan di atas dapat disimpulkan bahwa siswa me senang belajar Bahasa inggris dengan model pembelajaran berdiferensiasi pada materi report text dengan cara berdiskusi kelompok dengan rekan sejawat yang memilki minat yang sama pada konten materi, memahami materi report text yang bertujuan untuk menggambarkan secara umum keunikan hewan pilihannya berdasarkan ciri-ciri fisik, habitat, kebiasaan dan lainya menggunakan konsep mind mapping.

\section{Pembahasan}

Berdasarkan hasil temuan pada penelitian ini diperoleh bahwa hasil belajar siswa menggunakan model pembelajaran berdiferensiasi pada materi report text Ketuntasan belajar mengalami peningkatan dari kondisi awal pra siklus diperoleh 
$36,36 \%$ menjadi $66,67 \%$ pada siklus I dan $90,91 \%$ pada siklus II dengan standar kriteria ketuntasan minimum 75 . Hal ini berarti bahwa terjadi sebuah perubahan yang signifikan pada hasil belajar anak yang mencakup aspek kognitif, afektif, dan psikomotorik yang merujuk pada teori penelitian ini tentang hasil belajar (Sudjana: 2005:20).

Selanjutnya, berdasarkan hasil pengamatan rekan sejawat pada siklus I, suasana pembelajaran yang menyenangkan dan kondusif sejalan dengan kemampuan dan cara guru dalam mengelola kelas dan menghadirkan konsep pembelajaran berdiferensiasi yang proaktif memilih materi sesuai dengan minat, kesiapan siswa dan profil belajarnya yang hasilnya mampu meningkatkan hasil belajar siswa menjadi lebih baik (Suwartiningsih, 2021). Hal ini merujuk pada apa yang dikatakan James (2009:10) bahwa differentiated instruction is different from individualized instruction; It concerns with the students' readiness, interest, background knowledge, e teacher knowledge, planning, and implementing learning design of the differentiated instruction that give reasonable ranges of experiences to content, activities, and learning scale that suit them. Pemikiran tersebut diartikan secara bebas bahwa pengajaran diferensiasi berbeda dengan pengajaran secara individu, dimana pengajaran berdiferensiasi menyangkut kesiapan siswa, minat, latar belakang pengetahuan, pengetahuan guru, perencanaan, dan pelaksanaan desain pembelajaran dari pengajaran berdiferensiasi yang memberikan rentang pengalaman yang wajar pada konten, kegiatan, dan skala pembelajaran yang sesuai untuk murid.

Dari pemikiran tersebut, dipahami bahwa pembelajaran diferensiasi pada siklus I diyakini mampu memberi peningkatan dalam kualitas pembelajaran dan peningkatan hasil belajar siswa, hal ini disebabkan karena antusias, semangat dan motivasi siswa untuk mencapai prestasi yang tinggi dan mendapat nilai yang tinggi.

Selanjtunya, pada siklus II terjadi peningkatan baik dalam kualitas pembelajaran maupun peningkatan hasil belajar. Peningkatan kualitas pembelajaran terlihat dari meningkatnya semangat dan motivasi siswa dalam memepelajari materi report text dimana siswa senang dan lebih kreatif dalam menuangkan ide-idenya sehingga terbentuk produk report text yang bermakna dan berkualitas dalam wujud video presentasi, video rekaman presentasi visual, rekaman suara dan lembar kerja peserta didik sesuai dengan profil belajar merekahttps://www.youtube.com/watch?v=wiPwKhagsUk. Hal ini merujuk pada teori yang dikemukan oleh Heacox (2003).

Lebih lanjut, peningkatann hasil belajar siswa pada materi report text dengan model pembelajaran berdiferensiasi pada siklus II merupakan perbaikan beberapa hal pada proses pembelajaran pada diferensiasi konten, proses dan produk dari siklus I sehingga beberapa kendala yang menjadi kekurangan siswa menjadi tidak tampak. Peningkatan hasil belajar tersebut ditandai dengan meningkatnya kreativitas, semangat dan motivasi siswa, serta suasana belajar yang menyenangkan.

Kemudian, peningkatan hasil belajar yang signifikan dipengaruhi pula oleh beberapa faktor yakni faktor external dan internal pada murid. Adapun faktor eksternal yang mempengaruhinya antara lain: kompetensi pedagogis maupun professional guru mata pelajaran, konten materi pembelajaran yang mudah dipahami oleh siswa, proses pembelajran yang tersistematis, lingkungan kelas yang aman dan nyaman, serta dukungan komunitas belajar serta siswa yang saling bekerjasama antara satu dengan lainnya. Selain itu, beberapa faktor internal yang terdapat pada 
siswa antara lain: ketekunan, semangat, kerjasama dan kreativitas mereka yang mendukung antara satu dengan lainya (Dalyono, 2009).

Berdasarkan pemaparan di atas yang merujuk pada hasil temuan penelitian dapat dikatakan bahwa pembelajaran berdiferensiasi mampu menghadirkan pembelajaran yang menyenangkan bagi siswa dimulai dari diferensiasi pada konten materi, proses dan produk yang diekspetasikan dapat membangun kreativitas siswa sesuai dengan minat, kesiapan, dan profil belajarnya pada akhirnya mampu meningkatkan hasil belajar siswa. Selain itu, beberapa faktor internal dan eksternal yang mendukung pelaksanaan pembelajaran diferensiasi mampu meminimalisir kendala dalam pelaksanaan pembelajaran. Oleh karena itu, pembelajaran diferensiasi diyakini dapat meningkatkan hasil belajar siswa pada kelas IX.A di SMP Negeri 1 Sape semester genap tahun pelajaran 2020/2021.

\section{KESIMPULAN}

Berdasarkan hasil pembahasan, berikut ini dikemukakan kesimpulan sebagai jawaban pada rumusan pertanyaan penelitian, diantaranya:

1. Hasil belajar siswa pada materi report text pada mata pelajaran Bahasa Inggris melalui model pembelajaran berdiferensiasi pada Kelas IX.A di SMP Negeri 1 Sape tahun pelajaran 2020/2021 meningkat.

2. Peningkatan hasil belajar melalui pembelajaran diferensiasi dapat terlihat dari meningkatnya rasa senang, semangat dan motivasi siswa dalam memamhami materi report text yang dipengaruhi pula oleh faktor internal dan eksternal.

Ada beberapa saran dari hasil penelitian, pembahasan, dan kesimpulan penelitian ini:

1. Dinas Pendidikan dan Kebudayaan Kabupaten Bima hendaknya merancang program Musyawarah Guru Mata Pelajaran (MGMP) pada mata pelajaran Bahasa Inggris dengan model pembelajaran berdiferensiasi.

2. Bagi guru mata pelajaran Bahasa Inggris hendaknya perlu mengaplikasikan pembelajaran berdiferensiasi pada kelasnya sebagai upaya untuk memberi pembelajaran yang berkualitas dimulai dari diferensiasi konten, proses dan produk untuk meningkatkan hasil belajar siswa.

3. Sekolah seyogyanya mengaplikasikan model pembelajaran berdiferensiasi pada beberapa mata pelajaran yang bertujuan untuk mengembangkan kompetensi guru dan hasil belajar siswa.

\section{DAFTAR PUSTAKA}

Dalyono, M. (2009). Psikologi Pendidikan. Jakarta. Rineka Cipta

Darmawan, P. A dan Sujoko. E. (2013). Revisi Taksonomi Pembelajaran Benyamin S. Bloom: Satya Widya, Vol. 29, No.1. Juni 2013: 30-39

Hamalik, O. (1993). Media Pendidikan Cetakan ke VI. Bandung : Citra Aditya.

Hamalik, O. 2001. Proses Belajar Mengajar. Jakarta : Bumi Aksara.

Heacox, D., \& Ed, D. (2003). A CD-ROM of Customizable Forms for Differentiating Instruction in the Regular Classroom How to Reach and Teach. Free Spirit Publisghing. 
Jamoliddinova, N. (2019). Scientific Bulletin Of Namangan State University Differentiated Instructions In Language Classes : "One Size Does Not Fit All ." Scientifi Bulletinof Namangan State University.

Mulyasa, E. (2009). Praktik Penelitian Tindakan Kelas. Bandung: PT. Remaja

Rosdakarya.Purwanto. (2008). Evaluasi Hasil Belajar. Bandung: Pustaka Pelajar.

Sudjana, N dan Ibrahim. (2009). Penelitian dan Penilaian Pendidikan. Bandung: Sinar BaruAlgesindo.

Sudjana, N. (2005). Penilaian Hasil Proses Belajar Mengajar. Bandung: Remaja Rosdakarya

Suparwoto. (2004). Kemampuan Dasar Mengajar. Yogyakarta: FIP Universitas NegeriYogyakarta.

Suwartiningsih, S. (2021). Penerapan Pembelajaran Berdiferensiasi untuk Meningkatkan Hasil Belajar Siswa pada Mata Pelajaran IPA Pokok Bahasan Tanah dan Keberlangsungan Kehidupan di Kelas IXb Semester Genap SMPN 4 Monta Tahun Pelajaran 2020/2021. Jurnal Pendidikan dan Pembelajaran Indonesia (JPPI), 1(2), 80-94.

Tomlinson, C. A. (2001). How To Differentiate Instruction IN Mixed-Ability Classrooms (second). Assosiation for Suprvision and Curriculum Development (ASCD).

Trianto. (2011). Mendesain Model Pembelajaran Inovatif-Progresif: Konsep, Landasan, dan Implementasinya pada Kurikulum Tingkat Satuan Pendidikan (KTSP). Jakarta:Kencana. 